23 Nopember 2015

12:39

Nurhid Page 1 


\title{
HUBUNGAN TINGKAT PENGETAHUAN DENGAN MOTIVASI UNTUK BERHENTI MEMAKAI NAPZA PADA REMAJA DI PONPES SURYALAYA SURABAYA
}

\author{
Nila Armiati Fitrianingrum*, Nur Hidaayah** \\ (Stikes Yarsis, Jl. SMEA 57 Surabaya) \\ email: nur_hidy@yahoo.co.id
}

\begin{abstract}
The number of drug abusers has been increasing rapidly from year to year, so it can be considered to endanger the safety of the nation's next generation. The research was Purposed to analyze the relationship of knowledge and motivation to stop drug use in adolescents at boarding school students Suryalaya Korwil Inabah XIX Surabaya in East Java. The design of this research is correlational by nature analytical cross sectional approach. Population of all students at boarding school teen Suryalaya Korwil Inabah XIX Surabaya in East Java as much as 24 people until found 22 respondent. Sampling technique is simple random sampling. Instrument using a questionnaire. Processing of test data used was spearman rank through SPSS with significance level $\alpha=0.05$. Teenager in boarding school students Suryalaya Korwil Surabaya in East Java Inabah XIX obtained in the majority of students have good knowledge Inabah with half of the respondents have a high motivation. From the results of statistical tests in getting $\rho<\alpha$ is $0.002<0.05$ which means that Ho is rejected or no relationship between level of knowledge and motivation to stop drug use on adolescent students.

Conclusion the study is the higher level of knowledge, the higher the motivation to stop drug use. The importance of nurses providing motivation to the youth about the effects of addictive drugs so they do not re use it.
\end{abstract}

\begin{abstract}
Abstrak: Jumlah penyalahguna NAPZA telah meningkat secara cepat dari tahun ke tahun, hal ini dianggap membahayakan keselamatan generasi penerus bangsa. Tujuan penelitian mengetahui hubungan tingkat pengetahuan dengan motivasi untuk berhenti memakai NAPZA pada santri remaja di Pondok Pesantren Suryalaya Korwil Jatim Inabah XIX Surabaya. Desain penelitian ini analitik korelasional, menggunakan cross sectional. Populasinya semua santri remaja usia 12-21 tahun di Pondok Pesantren Suryalaya Korwil Jatim Inabah XIX Surabaya sebanyak 24 orang. Sampel penelitian adalah sebagian santri remaja sebanyak 22 orang. Teknik sampling: simple random sampling. Instrumen menggunakan kuesioner. Pengolahan data yang digunakan adalah uji Rank spearman melalui SPSS dengan tingkat kemaknaan $\alpha=0,05$. Hasil : sebagian besar $(59 \%)$ santri memiliki pengetahuan baik, setengah $(50 \%)$ responden memiliki motivasi tinggi. Hasil uji statistik didapatkan $\rho<\alpha(0,002<0,05)$ berarti Ho ditolak atau ada hubungan antara tingkat pengetahuan dengan motivasi untuk berhenti memakai NAPZA pada santri remaja. Simpulan: semakin tinggi tingkat pengetahuan maka semakin tinggi pula motivasi untuk berhenti memakai NAPZA. Perawat harusnya memberikan informasi dan motivasi tentang pentingnya dampak NAPZA bagi tubuh agar mereka tidak kembali menggunakannya.
\end{abstract}

Kata kunci : Pengetahuan, Motivasi 


\section{PENDAHULUAN}

NAPZA merupakan kepanjangan dari Narkotika, Alkohol, Psikotropika, dan Zat Adiktif lainnya, sering dikenal dengan Narkoba. Jumlah penyalahguna NAPZA telah meningkat secara cepat dari tahun ke tahun, sehingga dapat dianggap membahayakan keselamatan generasi penerus bangsa yang menggunakannya. Masalah penyalahgunaan NAPZA sudah menjadi masalah global yang harus ditanggulangi sesegera mungkin, hal ini dilihat dari semakin meningkatnya pengguna NAPZA baik secara kualitas maupun kuantitas. Penggunaan NAPZA tidak hanya terdapat pada golongan menengah keatas melainkan juga pada penduduk miskin, tidak hanya di kota besar, tetapi juga sudah menyebar ke desa terpencil, bahkan pengguna NAPZA tidak hanya pada kalangan orang dewasa melainkan juga pada usia anak dan remaja. Jaringan narkoba internasional tidak akan berhenti memasukan barang terlarang itu ke seluruh Indonesia melalui pelabuhan dan bandara. Hal ini terjadi karena masih banyak permintaan barang terlarang itu di Indonesia (BNN 2010).

Menurut data United Nations Drugs Control Programme (UNDCP) tahun 2000 , kurang lebih 200 juta orang telah menggunakan barang berbahaya ini di seluruh dunia, dari jumlah tersebut $1 \%$ berada di Indonesia. Fakta menunjukkan bahwa sekitar 3,81 juta penduduk Indonesia adalah pengguna narkoba dan tercatat sekitar 19 persen dari jumlah remaja di Indonesia atau sekitar 14 ribu remaja, diindikasikan menjadi pengguna narkoba. Fenomena ini akan menjadi pertanda buruk bagi bangsa jika persoalan tersebut tidak di carikan solusinya (BNN, 2011).

Menurut studi pendahuluan yang di lakukan peneliti di Pondok Pesantren Suryalaya Korwil Jatim Inabah XIX jalan Raya Semampir 43-47 Surabaya. Didapatkan data santri tahun 2007 bahwa dari 53 orang santri, yang mulai menggunakan NAPZA pada usia remaja (12-21) adalah sebanyak 42 orang (79,3\%). Data tahun 2008 dari 45 santri yang mulai menggunakan NAPZA pada usia remaja (12-21) adalah sebanyak 38 orang $(84,4 \%)$. Data tahun 2009 dari 52 santri yang mulai menggunakan NAPZA pada usia remaja $(12-21)$ adalah sebanyak 45 orang $(86,6 \%)$. Data tahun 2010 dari 60 santri yang mulai menggunakan NAPZA pada usia remaja (12-21) adalah sebanyak 52 orang $(86,6 \%)$. Data tahun 2011 dari 55 santri yang mulai menggunakan NAPZA pada usia remaja (12-21) adalah sebanyak 48 orang $(87,2 \%)$. Dengan data tersebut dapat diketahui bahwa dalam 5 tahun terakhir (tahun 2007-2011) di Pondok Pesantren Suryalaya Korwil Jatim Inabah XIX sebagian besar mulai menggunakan NAPZA pada usia remaja (12-21 tahun), hal ini membuktikan bahwa jumlah pengguna NAPZA baik di Pondok Pesantren Suryalaya Korwil Jatim Inabah XIX maupun di Indonesia usia remaja meningkat dari tahun ke tahun (Kauma, 2002).

Ketidaktahuan tentang NAPZA adalah awal pemakaian dan penyalahgunaan NAPZA dan dampak negatifnya ternyata berakibat fatal. Berikut ini adalah beberapa faktor yang mendorong seseorang memakai NAPZA yaitu: Ketidaktahuan, ingin kenikmatan yang cepat, alasan internal (ingin tahu, ingin dianggap hebat, rasa setia kawan, rasa kecewa atau frustasi, ingin bebas dari rasa sakit, ingin menikmati rasa gembira atau tampil lincah dan energik), alasan keluarga, alasan orang lain (tipu daya, bujuk rayu, paksaan), jaringan peredaran luas sehingga narkoba mudah didapat, strategi pemasaran yang jitu. 
Pemakai NAPZA dapat mengalami kerusakan organ tubuh dan menjadi sakit sebagai akibat langsung adanya zat-zat NAPZA dalam darah, misalnya kerusakan paru-paru, ginjal, hati, otak, jantung, usus, dan sebagainya. Kerusakan jaringan pada organ tubuh akan merusak fungsi organ tubuh sehingga timbul berbagai penyakit. Pemakai NAPZA juga dapat terkena penyakit infeksi, seperti hepatitis, HIV/AIDS, penyakit menular seksual (PMS). Selain itu kerusakan yang tidak kalah bahayanya adalah gangguan psikologis serta kerusakan mental dan moral (Partodiharjo, 2010).

Menyadari bahwa permasalahan tersebut di atas mengganggu perkembangan dan masa depan remaja atau generasi muda, maka upaya-upaya pencegahan sendiri mungkin amat penting menurut BNN tahun 2010 ada 3 langkah penting dalam menyikapi semakin meluasnya pengguna NAPZA di usia remaja, yaitu pertama: pengetahuan yang cukup tentang narkoba, memberikan kasih sayang yang cukup terhadap para remajanya. Kedua: lingkungan sekolah melakukan pembinaan dan pengawasan secara rutin terhadap siswa baik dengan melibatkan pihak lain (kepolisian, komite sekolah, orangtua), menggiatkan kegiatan ekstrakurikuler yang bermanfaat, serta mengembangkan suasana yang nyaman dan aman bagi remaja untuk belajar. Ketiga: dalam lingkungan masyarakat, para tokoh agama, perangkat pemerintahan di semua tingkatan perlu bersikap tegas dan konsisten terhadap upaya pencegahan penyalahgunaan narkoba dilingkungannya masingmasing yang didukung penuh oleh pihak keamanan dan kepolisian. Mereka perlu terus menerus memberi penyadaran dan informasi pada seluruh warga masyarakat akan bahaya mengkonsumsi narkoba tanpa indikasi medik dan pengawasan ketat dari dokter dalam rangka penyembuhan.

Dari uraian di atas, maka peneliti tertarik untuk mengangkat judul penelitian: "hubungan tingkat pengetahuan dengan motivasi untuk berhenti memakai NAPZA usia remaja di pondok pesantren Suryalaya Korwil Jatim Inabah XIX Surabaya"

\section{METODE}

Penelitian ini menggunakan jenis analitik dengan pendekatan cross sectional. Populasinya santri remaja usia 12-21 tahun sebanyak 24 orang. Sampel sebagian santri remaja usia 1221 tahun di Pondok Pesantren Suryalaya Korwil Jatim Inabah XIX Surabaya, jumlah 22 responden. Teknik pengambilan sampel adalah Simple Random Sampling. Variabel independen: tingkat pengetahuan remaja tentang NAPZA. Variabel dependennya: motivasi untuk berhenti memakai NAPZA. Instrumen: kuesioner. Analisis data menggunakan uji rank spearman, signifikansi $\alpha=0,05$.

\section{HASIL DAN PEMBAHASAN}

\section{a. Hasil}

Penelitian ini dilakukan di Pondok

Pesantren Suryalaya Inabah XIX Surabaya. Hasil penelitian pada 22 santri, didapatkan: hampir seluruh responden $(77,3 \%)$ berumur $18-21$ tahun. Hampir seluruh responden $(81,8 \%)$ berpendidikan menengah. Hampir seluruh responden $(77,3 \%)$ bekerja swasta. Sebagian besar $(59 \%)$ memiliki pengetahuan baik. Dan setengah responden $(50 \%)$ mempunyai motivasi tinggi untuk berhenti memakai NAPZA. Hasil tabulasi silang menunjukkan, 13 santri $(100 \%)$ yang memiliki pengetahuan baik, sebagian besar $(69,2 \%)$ atau 9 santri memiliki motivasi tinggi. Uji Rank Spearman ditemukan $\rho=0,002<\alpha=0,05$ berarti Ho 
ditolak "ada hubungan antara tingkat pengetahuan dengan motivasi untuk berhenti memakai NAPZA pada santri remaja".

\section{b. Pembahasan}

1. Tingkat pengetahuan

Sebagian besar $(59 \%)$ dari 22 responden memiliki pengetahuan yang baik tentang bahan makanan dan minuman yg mengandung zat adiktif, dampak, tujuan dilakukannya rehabilitasi serta penanggulangan NAPZA (sesuai data pada kuesioner). Hampir seluruh responden tidak tahu tentang pengertian NAPZA.

Menurut Notoadmodjo (2003) Umur, Tingkat pendidikan, Pengetahuan sebelumnya, Lingkungan, Pekerjaan, Informasi/media massa, Sosial budaya \& ekonomi, Pengalaman akan mempengaruhi tingkat pengetahuan individu. Data umum penunjang didapatkan, hampir seluruh responden $(77,3 \%)$ berumur $18-24$ tahun, usia tersebut mempunyai pengalaman yang lebih banyak, dan informasi yang banyak pula baik tentang NAPZA maupun pendidikan lainnya.

Kegiatan dipondok Suryalaya salah satunya adalah dari petugas kesehatan yang memberikan informasi seputar NAPZA setiap dua minggu sekali, serta pendidikan tentang agama yang diberikan setiap hari oleh pengelola pondok seperti sholat, dzikir, mengaji dan hukum NAPZA. Dengan demikian santri menjadi lebih mengerti dan memahaminya, sehingga santri lebih beriman dan bertaqwa kepada Allah SWT dengan melaksanakan shalat, dzikir, dan mengaji. Delapan belas responden mempunyai pendidikan menengah (SMA sederajat). Pekerjaan, hampir seluruh responden $(86,3 \%)$ bekerja swasta dan wiraswasta seperti sebagai bartender, pramuniaga, pramusaji, sopir, pegawai pom bensin, pedagang dan percetakan mempunyai peluang yang sangat besar untuk terjerumus ke pemakaiaan NAPZA.

2. Motivasi untuk berhenti memakai NAPZA

Setengah $\quad(50 \%)$ dari 22 responden memiliki motivasi tinggi untuk berhenti memakai NAPZA. Hal ini terbukti pada hasil kuesioner didapatkan motivasi responden baik untuk tidak memakai NAPZA, tidak akan menerima ajakan teman, keinginan kuat untuk lepas dari NAPZA, tidak ingin coba lagi, tidak akan sembunyi dalam memakai NAPZA, siap hidup bermasyarakat tanpa NAPZA. Serta kurang dari setengah responden menyatakan kurang dalam motivasi ikut beberapa kegiatan dalam program rehabilitasi dan ingat Allah ketika menggunakan NAPZA.

Motivasi dipengaruhi persepsi individu, tingkat pendidikan, pengalaman masa lampau, keinginan atau harapan dimasa depan, usaha atau dorongan kuat dari dalam diri individu serta lingkungan, pengetahuan/ informasi yang didapat sebelumnya, sistem imbalan, dorongan atau bimbingan orang lain (Bastable, 2002). Berdasarkan data umum: hampir seluruh responden $(77,3 \%)$ berumur 18 24 tahun, dimana usia remaja akhir memiliki tingkat kematangan yang lebih baik, dibanding usia remaja menengah atau awal sehingga, pada usia ini sudah mampu menganalisis hal baik atau buruk. Hampir seluruh responden $(81,8 \%)$ berpendidikan menengah (SMA sederajat). Pendidikan menengah mempunyai pengaruh cukup tinggi mencegah penggunaan NAPZA. Faktor yang lain yang mendukung terhadap motivasi untuk berhenti menggunakan NAPZA adalah faktor pekerjaan. 
Seorang yang terbiasa bekerja dan mendapatkan penghasilan akan merasakan adanya kenikmatan di dalam menerima penghasilan tersebut sehingga semua kebutuhan dirinya akan terpenuhi dari penghasilan yang didapat, sedangkan responden yang berada di pondok Inabah secara otomatis dia akan berhenti untuk bekerja, sehingga responden termotivasi untuk berhenti menggunakan NAPZA.

3. Hubungan tingkat pengetahuan dengan motivasi untuk berhenti memakai NAPZA.

Uji Rank Spierman didapatkan $\rho=0,002<\alpha=0,05$ sehingga Ho ditolak berarti ada hubungan tingkat pengetahuan dengan motivasi untuk berhenti memakai NAPZA pada santri remaja. Faktor yang mempengaruhi motivasi santri untuk berhenti memakai NAPZA adalah tingkat pengetahuan yang sebagian besar $(59 \%)$ yaitu 13 dari 22 responden memiliki pengetahuan yang baik dan hampir setengahnya $(50 \%)$ yaitu 11 remaja diantaranya memiliki motivasi yang tinggi untuk berhenti memakai NAPZA. Menurut Soetijiningsih (2003), bahwa makin tinggi pendidikan individu makin cepat penerimaannya terhadap suatu informasi khususnya informasi tentang NAPZA yang diperoleh dari melihat, mendengar dan membaca. Sesuai hasil wawancara selama pengambilan data penelitian, didapatkan santri pengguna NAPZA merasa dirinya sudah tidak diharapkan lagi dimasyarakat. Motivasi yang kuat yang timbul dari dalam dirinya akan sangat membantu untuk berhenti memakai NAPZA. Saling bertukar informasi, berdiskusi dalam memecahkan masalah, memberikan nasehat untuk tetap menjalankan kegiatan rehabilitasi. Hubungan yang harmonis dan penuh kasih sayang antar penghuni pondok baik petugas maupun sesama penghuni membuat santri pemakai NAPZA merasa optimis karena masih banyak orang yang peduli. santri pemakai NAPZA memiliki kepercayaan diri melanjutkan belajar atau bekerja.

\section{SIMPULAN}

1. Santri remaja di Pondok Pesantren Suryalaya Korwil Jatim Inabah XIX Surabaya sebagian besar memiliki pengetahuan baik tentang mengenal jenis zat adiktif dalam makanan, dampak, tujuan rehabilitasi serta penanggulangannya.

2. Santri remaja di Pondok Pesantren Suryalaya Korwil Jatim Inabah XIX Surabaya setengahnya memiliki motivasi tinggi tentang kesembuhan, keberhasilan setelah mengikuti rehabilitasi, berkomitmen hidup di masyarakat tanpa NAPZA .

3. Ada hubungan tingkat pengetahuan dengan motivasi untuk berhenti memakai NAPZA pada santri remaja di Pondok Pesantren Suryalaya Korwil Jatim Inabah XIX Surabaya.

\section{DAFTAR PUSTAKA}

Arikunto, Suharsimi. 2006. Prosedur Penelitian Suatu Pendekatan Praktik. Jakarta: Rineka Cipta

Badan Narkotika Nasional. 2011. Mengenal Penyalahgunaan Narkoba. Jakarta Timur: BNN

Bastable, Susan. 2002. Perawat Sebagai Pendidik. Jakarta: Buku Kedokteran EGC.

BNN. 2011. Tiga Langkah Membangun Remaja Bebas Narkoba. www.bnn.go.id. Artikel diakses tanggal 22 mei 2010

Moekijat,Suprihanto. 2003. Motivasi di Dunia Psikologi. http://elearningpendidikan.com. 
Artikel di akses tanggal 11 juni 2012

Notoadmodjo, Soekidjo. 2003.

Pendidikan dan Perilaku

Kesehatan. Jakarta: Rineka Cipta.

Sumiati, dkk. 2009. Asuhan

Keperawatan Pada Klien

Penyalahgunaan \&

Ketergantungan NAPZA. Jakarta:

Trans Info Media

Surbakti. 2009. Kenalilah Anak Remaja Anda. Jakarta: Kalam Mulia Tembong. 